\title{
Zinc Iodide-Osmium Tetroxide (ZIO) Reactive Golgi Apparatus in the Principal Cells of Dog Epididymal Epithelium
}

\author{
El Tetróxido de Zinc Iodide-Osmio (ZIO) Reactiva el Aparato de Golgi en las Células Principales \\ del Epitelio Epididimal del Perro
}

"Bruno Cesar Schimming \& **Carlos Alberto Vicentini

SCHIMMING, B. C. \& VICENTINI, C. A. Zinc iodide-osmium tetroxide (ZIO) reactive Golgi apparatus in the principal cells of dog epididymal epithelium. Int. J. Morphol., 23(4):337-344, 2005.

SUMMARY: The cisternae of the Golgi apparatus of dog epididymal principal cells were labeled by the zinc iodide-osmium tetroxide method (ZIO). These cisternae were observed in the supranuclear region of the cytoplasm of the epididymal principal cells. Abundant endoplasmic reticulum cisternae, multivesicular bodies, mitochondria, lysosomes and vesicular elements of variable size were also found in this region, all associated with the sacks of the well-developed Golgi apparatus. The use of the ZIO method facilitates the observation and identification of the cisternae of the Golgi apparatus, thus permitting a correlation between structure and function in the so-called Golgi area. These ultrastructural characteristics support the secretory role of epididymal principal cells in the dog.

KEY WORDS: Epididymis; Principal cells; Golgi apparatus; ZIO method.

\section{INTRODUCTION}

The mammalian epididymis is a site of testicular fluid reabsorption and secretory activity, favoring the maturation of spermatozoa, which involves a series of morphological, physiological and biochemical alterations (Robaire \& Hermo, 1988; López et al., 1989). The mechanism leading to these alterations is still not well understood, although literature data suggest that sequential protein secretion by the lining epithelium of the different epididymal regions plays a role in the process of spermatic maturation (Bedford, 1994; Cooper, 1995). The mammalian epididymis secretes numerous proteins important for sperm maturation. Some proteins have been the focus of a number of studies and have been implicated in sperm/egg fusion (Roberts et al., 2002).

The epithelium lining of the epididymal duct of mammals consists of a cell population that shows a low mitotic activity compared to the seminiferous epithelium (Clermont \& Flannery, 1970). Several cell types have been described in the epididymal epithelium of various species, with this cell population mainly being represented by principal, basal and apical cells (Arrighi et al., 1993; Schimming \& Vicentini, 2001). These cells are supposed to perform different functions, a fact confirmed by ultrastructural studies such as that of Arrighi et al., who suggested that the ultrastructure of the epithelium reflects the main functions of the epididymis (absorption, secretion and ions exchange).

The epithelial principal cells are the predominant cell type of the epididymis (Robaire \& Hermo), and these cells based on the ultrastructural studies carried out in mammals generally, show the following characteristics: microvilli at the luminal border and a supranuclear cytoplasm rich in organelles, such as mitochondria, rough and smooth endoplasmic reticulum, free ribosomes, numerous vacuoles and vesicles, multivesicular bodies, a large Golgi apparatus, membrane-delimited granules, caveolae, and lysosomes (Hamilton, 1975). The infranuclear cytoplasm of principal cells contains mitochondria and membrane-delimited granules (Ramos \& Dym, 1977), as well as smooth endoplasmic reticulum cisternae (Vicentini et al., 1985).

According to ultrastructural observations, principal cells have been shown to be involved in the secretory and absorption functions. Although difficult to characterized, merocrine secretion by principal cells of the lining epithelium has been suggested for the epididymis of different mammals

\footnotetext{
* Department of Veterinary Medicine, Agrarian Sciences Faculty, University of Marília, UNIMAR, Marília, São Paulo, Brazil.

** Department of Biological Sciences, Faculty of Sciences, UNESP, Bauru, São Paulo, Brazil.
} 
(Vicentini \& Orsi, 1989). The exact secretion mechanism is still poorly understood, although glycoprotein secretion has been accepted (Voglmayr et al., 1985). Hamilton and Robaire $\&$ Hermo postulated that these cells secreted of a variety of substances, such as ions, small organic molecules, and glycoproteins, which have been suggested to have a role in sperm maturation.

Hoffer et al. (1973) and Ramos \& Dym have suggested that the principal cells of the mammalian epididymis perform synthesis and secretory activities, based on the presence of numerous rough endoplasmic reticulum lamellae and a well-developed Golgi apparatus.

The absorption function of principal cells is supported mainly by morphological evidence showing the presence of lysosomal structures, called multivesicular bodies, in the cytoplasm of epididymal cells in the rat (Hoffer et al.) and monkey (Ramos \& Dym). These multivesicular bodies play a role in the transport and digestion of material absorbed by epididymal cells (Greenberg \& Forssmann, 1983).

In view of the morphological and physiological complexity of the mammalian epididymis, the aim of the present ultrastructural study was to identify cytoplasmic sites containing cisternae of the Golgi apparatus in epididymal principal cells of the dog.

\section{MATERIAL AND METHOD}

The epididymides were dissected from five sexually mature mongrel dogs (Canis familiaris, L.) obtained from the Central Animal House, Botucatu Campus, UNESP, and submitted to a zinc iodide-osmium tetroxide (ZIO) cytochemical reaction according to the standard technique of Reinecke \& Walther (1978).

After collection, the epididymal segments were cut into 1-mm thick fragments with a stainless steel blade and fixed in $2.5 \%$ glutaraldehyde in $0.1 \mathrm{M}$ phosphate buffer, $\mathrm{pH}$ 7.3 , for 24 hours. The fragments were then washed three times with $0.1 \mathrm{M}$ phosphate buffer, $\mathrm{pH} 7.3$, and post-fixed in $1 \%$ osmium tetroxide in the same buffer for $2 \mathrm{~h}$. The material was then washed twice with $8.5 \%$ sucrose solution in $0.1 \mathrm{M}$ phosphate buffer, $\mathrm{pH} 7.3$ (10 min each), followed by four washes ( $5 \mathrm{~min}$ each) with Tris-aminomethane buffer containing $1.13 \mathrm{M} \mathrm{NaCl}, 0.011 \mathrm{M} \mathrm{CaCl}_{2}, 0.03 \mathrm{M} \mathrm{MgCl}_{2}$ and $0.01 \mathrm{M}$ Tris-aminomethane, $\mathrm{pH} 4.5$.

The fragments were then incubated in specific medium (ZIO), in the dark, at low temperature $\left(8-10^{\circ} \mathrm{C}\right)$ for 21h. The ZIO incubation medium was prepared as follows: $3 \mathrm{~g}$ zinc powder in $10 \mathrm{ml}$ distilled water was added to $1 \mathrm{~g}$ iodide resuspended in $10 \mathrm{ml}$ distilled water, the two solutions were mixed with Tris-aminomethane buffer (1:1), and 4 parts of the final solution were mixed with 1 part $2 \%$ osmium tetroxide in distilled water. The specimens were then washed in the same buffer (Tris-aminomethane), dehydrated and embedded in Araldite resin using routine procedures.

The sections were examined and documented using a Philips EM 100 transmission electron microscope at the Electron Microscopy Center, Institute of Biosciences of Botucatu, UNESP.

\section{RESULTS}

The cytoplasm of the principal cells could be divided into three regions: basal region, i.e., the region that extends from the basement membrane to the upper limits of the nuclear envelope, supranuclear region, and the apical region located close to the cell apex and tubular lumen. The most notable characteristic of the supranuclear region of dog epididymal principal cells was the presence of the Golgi apparatus, detected by the ZIO method, which consisted of numerous cisternae and vesicular elements of variable size, occupying most of the supranuclear cytoplasm (Figs. 1D, $2 \mathrm{~A}, \mathrm{C}$ and $3 \mathrm{~A}, \mathrm{~B})$.

Transverse or tangential sections along the extension of the Golgi apparatus showed alternating compact and noncompact zones. The compact zones corresponded to the sacks or stacked lamellae, while the non-compact zones consisted of dilated membranous tubules bound to the adjacent lamellae through bridges. This zone was less compacted and contained numerous dilated membranous tubules, which connected the sacks of adjacent lamellae (Fig. 1C).

The cisternae were stacked and formed the so-called compact zone of the Golgi apparatus. In this zone, the elements on the cis side of the Golgi apparatus, appeared as a series of elongated and flattened rudimentary membranes, often with circular arrangement, which were connected by electron-dense bridges and interrupted by numerous vesicles called wells. On the trans face, the sacks were found to be more dilated and not interrupted by wells (Figs. 1A-D).

On the cis side of the Golgi apparatus some small vesicles, transport or transfer vesicles, could be observed, which seemed to originate from the endoplasmic reticulum and to be incorporated into the cisternae on the cis side of the sack (Figs. 1A-D and 3A,B). 

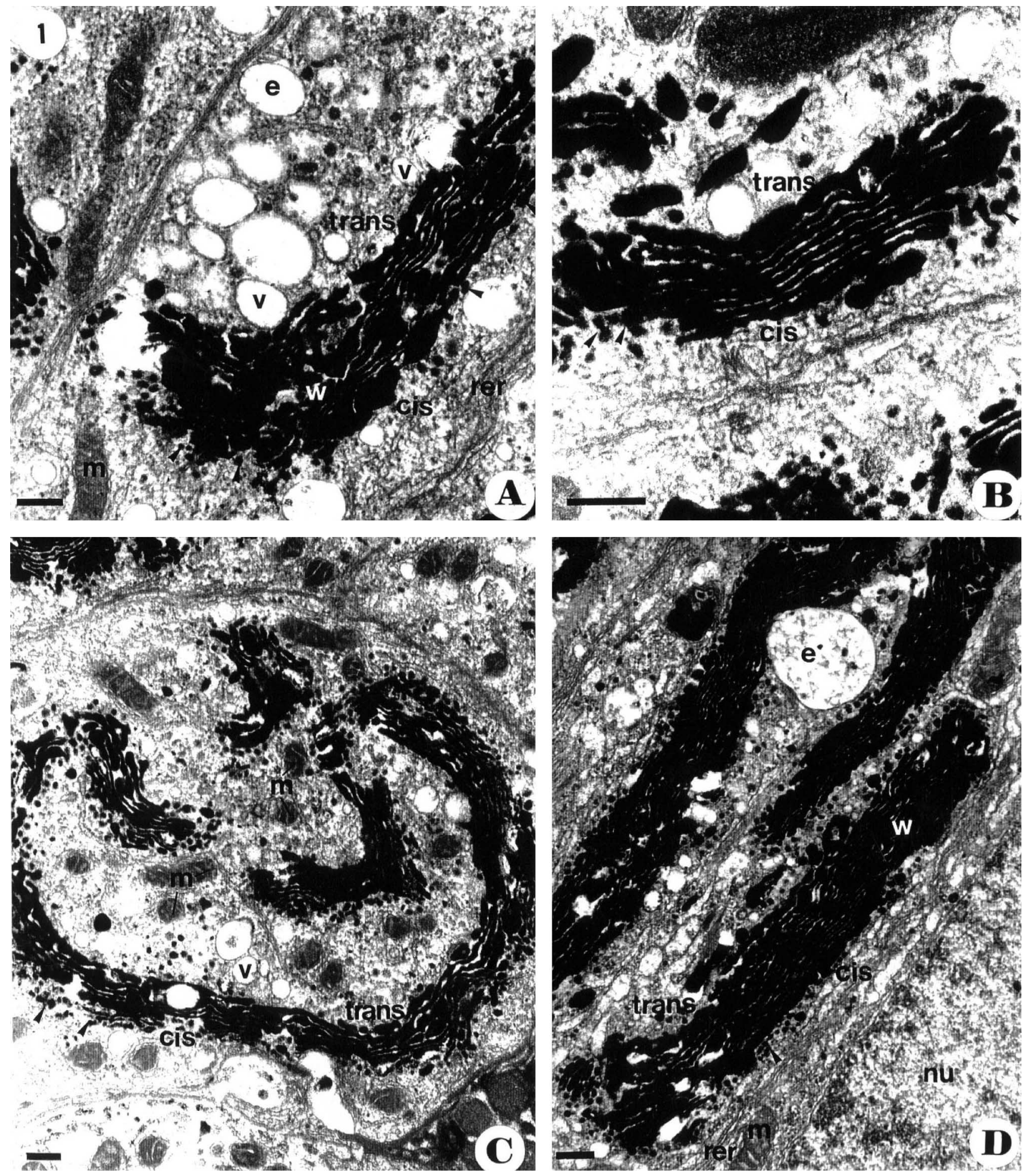

Fig. 1. Golgi area in the supranuclear cytoplasm. Indicated are the cis and trans side of the Golgi apparatus, transport vesicles (arrowhead), well (w) and secretory vesicles (v). Mitochondria (m), endosomes (e), rough endoplasmic reticulum (rer) and nucleus (nu) are also observed. Bar $=0.4 \mu \mathrm{m}$. 

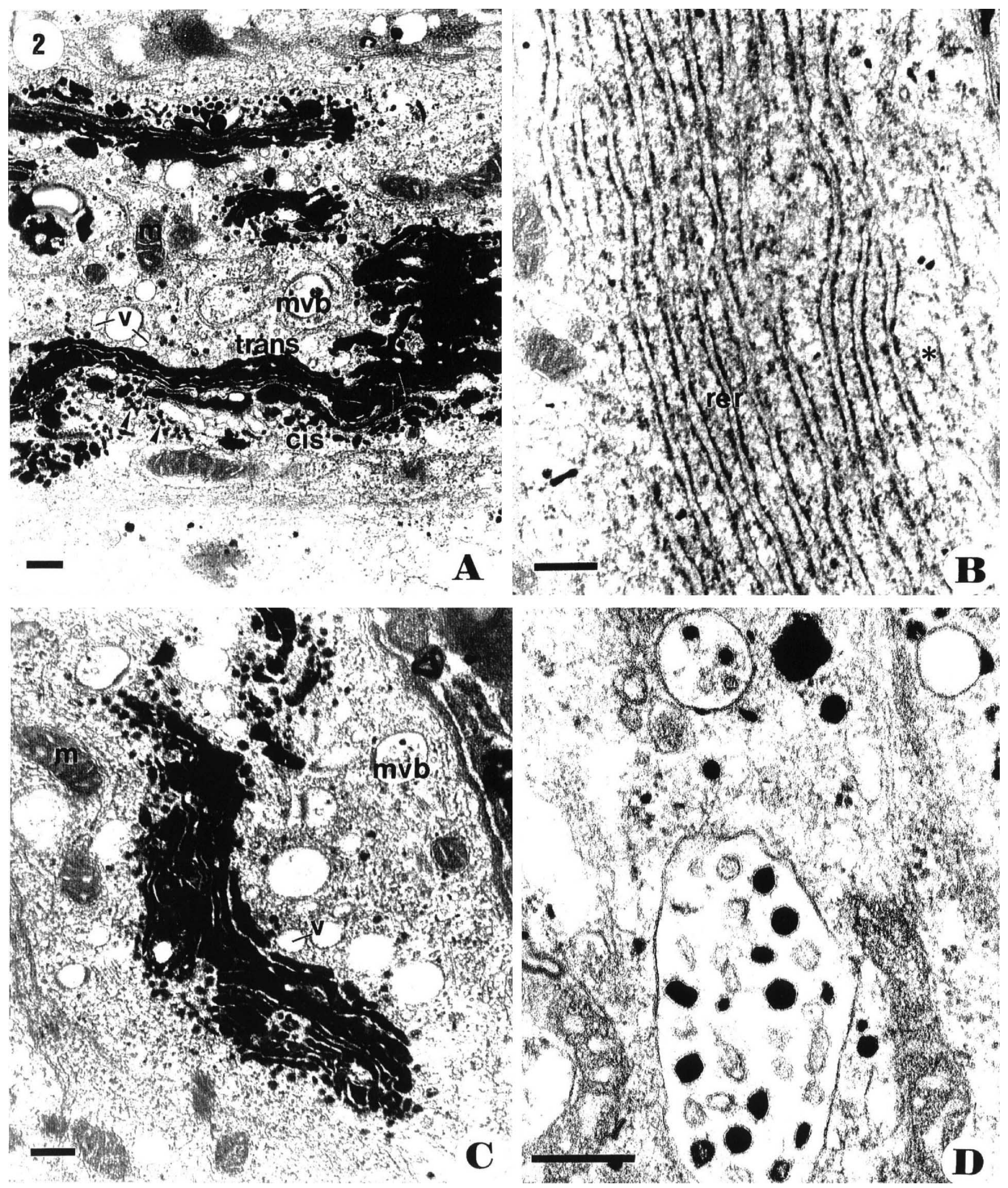

Fig. 2. Supranuclear cytoplasm of principal cells. A, Golgi area consisting of transport vesicles (arrowhead), secretory vesicles (v), mitochondria (m) and multivesicular bodies (mvb). B, Tubular (rer) and flattened (asterisk) cisternae of the rough endoplasmic reticulum. C, Multivesicular bodies (mvb), mitochondria (m) and secretory vesicles (v) in the Golgi area. D, Multivesicular bodies containing deeply labeled vesicular elements. Bar $=0.4 \mu \mathrm{m}$. 

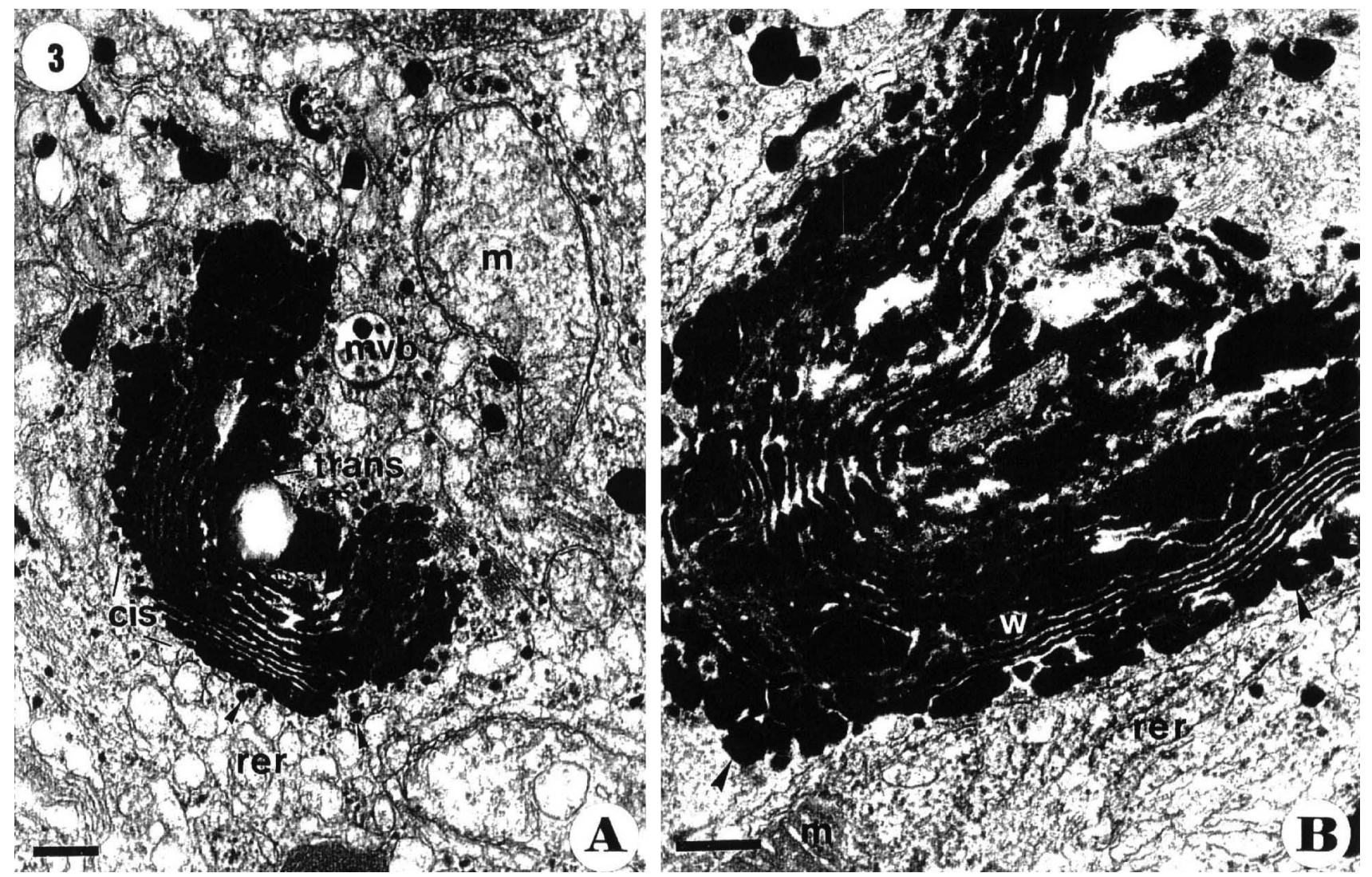

Fig. 3. Golgi area. Note the cis and trans side of the Golgi apparatus, transport (arrowhead) and well (w) vesicles, mitochondria (m), multivesicular bodies (mvb) and rough endoplasmic reticulum (rer). Bar $=0.4 \mu \mathrm{m}$.

On the trans face of the Golgi apparatus, numerous vesicles of variable size could be noted, which were larger than the transport vesicles and are called secretory vesicles, and which were similar in size and appearance to the uncoated vesicles found in the apical cytoplasm (Figs. 1A$\mathrm{D}$ and $2 \mathrm{C})$.

Two types of endoplasmic reticulum cisternae could be differentiated: the first type was generally flattened, although slightly distended, and contained granulofilamentous material. Numerous ribosomes were found to be associated with these membranes, and led to their granulated aspect. These rough endoplasmic reticulum cisternae were observed in the basal cytoplasm, the supranuclear region and along the lateral plasma membranes. The second type of endoplasmic reticulum cisternae was observed in the supranuclear region and in the apical cytoplasm of the cells, and consisted of distended, tubular cisternae, which occasionally showed ribosomes associated with their membranes and contained granulofilamentous material. These scattered cisternae of the rough endoplasmic reticulum were abundant in the Golgi area, where they were intermingled with Golgi lamellae (Figs. 1D, 2B and 3A,B).
Multivesicular bodies, mitochondria and few lysosomes were also found in association with the Golgi area (Figs. 1A,C, 2A,C,D and 3A). Endosomes were also observed (Fig. 1D). A strong ZIO reaction is evident over vesicular elements of the multivesicular bodies (Fig. 2D).

\section{DISCUSSION}

Based on the criteria of classification for the principal cell cytoplasmic regions proposed by Robaire $\&$ Hermo, the cytoplasm of these epithelial cells in the epididymis of the dog, could be divided into three regions: basal, supranuclear and apical.

The supranuclear cytoplasm of dog epididymal principal cells was characterized by the presence of the Golgi apparatus, scattered cisternae of the rough endoplasmic reticulum, multivesicular bodies, mitochondria and some lysosomes, characteristics also observed in other studies for the rat epididymis (Robaire \& Hermo; Hermo, 1995). 
Vicentini \& Orsi postulated that the supranuclear cytoplasm of the epididymal principal cells of the golden hamster mainly consists of a well-developed Golgi apparatus, which is formed by lamellar cisternae that extend into small and clear apical vacuoles arranged in the form of a supranuclear necklace and with cis-trans ends. In addition to the clear vacuoles, the Golgi apparatus is associated with multivesicular bodies and the cisternae of the rough endoplasmic reticulum.

The ultrastructural characteristics of the dog epididymal principal cells described above, demonstrate that these cells possibly secrete compounds into the tubular lumen. Principal cells possess a well-developed Golgi apparatus and numerous rough endoplasmic reticulum cisternae, suggesting that these cells are able to synthesize and secrete proteins or glycoproteins, similarly to what is observed for other mammalian species (Hamilton; Robaire \& Hermo; Goyal \& Williams, 1991; Arrighi et al.).

López et al. suggested that the abundant endoplasmic reticulum and the Golgi apparatus associated with vacuoles and vesicles of different sizes, can be considered ultrastructural evidence for the secretory role of the mammalian epididymis. It is also known that the epididymal head secretes glycoproteins that bind to spermatozoa and permit their passage inside the epididymis (Flickinger et al., 1978).

The principal cells of the dog epididymal segments did not present the homogenous granules typical for the Golgi area of other protein/glycoprotein secretory cells, such as salivary or pancreatic cells (Goyal \& Williams). Based on a similar observation, Hoffer et al. suggested that epididymal proteins synthesized in the rough endoplasmic reticulum migrate to the Golgi apparatus.

Autoradiographic studies have demonstrated the passage of proteins/glycoproteins from the rough endoplasmic reticulum to the Golgi cisternae and then to the coated vesicles, which in turn release their content into the tubular lumen (Flickinger et al., 1984). Nicander \& Malmqvist (1977) provided ultrastructural evidence that the small vesicles, similar to those present in the Golgi area, are involved in protein secretion in the initial segment of the mammalian epididymis.

In the present study, numerous apparently empty vesicles were observed in the Golgi area (supranuclear cytoplasm) and in the apical cytoplasm of principal cells. However, considering only morphological characteristics, it is not possible to determine whether these vesicles are exclusively involved in secretion or reabsorption.
Probably, the mechanisms of epididymal glycoprotein synthesis do not differ from the model proposed by Neutra \& Leblond (1966), who suggested that after protein synthesis in the rough endoplasmic reticulum, the glycocomponent is added at the level of the Golgi apparatus. These macromolecules are then transported by the small and clear vacuoles associated with the Golgi complex (Nicander \& Plöen, 1979).

It is generally accepted that partially glycosylated proteins are transported from the endoplasmic reticulum to the saccules of the Golgi apparatus. The structural elements considered to be involved in this transport are the small intermediate or transfer vesicles, seen between the overlying endoplasmic reticulum and the cis-element of the Golgi sacks. However, the unequivocal demonstration that all of the vesicles carry proteins unidirectionally from the endoplasmic reticulum to the Golgi apparatus has yet to be fully documented (Hermo et al., 1991).

It is believed that the same occurs during the secretory process in the principal cells of the dog epididymis, based on the presence of a well-developed Golgi apparatus, abundant endoplasmic reticulum cisternae associated with the Golgi complex, and transport vesicles on the cis side and secretory vesicles on the trans side of the Golgi apparatus. Proteins/glycoproteins are thus transported from the endoplasmic reticulum to the sacks of the Golgi apparatus. The structural elements involved in this transport are the transport or transfer vesicles observed between the endoplasmic reticulum borders and on the cis side of the Golgi cisternae. The secretory vesicles, in turn, release their protein/glycoprotein content into the tubular lumen. In addition, one can suppose the occurrence of a possible continuous renewal of glycoproteins on the surface of epididymal duct cells as postulated by Vicentini \& Orsi.

Based on these morphological peculiarities, we suggest that the principal cells of the dog epididymis are in fact secretory cells. The present ultrastructural findings indicate that these cells secrete at least proteins, but almost certainly also glycoproteins as demonstrated by positive histochemical reactivity to neutral and acid glycosaminoglycans (Schimming \& Vicentini, 2000).

\section{ACKNOWLEDGMENTS}

The authors would like to thank CNPq (Conselho Nacional de Desenvolvimento Científico e Tecnológico, proc. 141512/95-4) for partial financial support of this work. 
SCHIMMING, B. C. \& VICENTINI, C. A. El tetróxido de zinc Iodide-Osmio (ZIO) reactiva el aparato de Golgi en las células principales del epitelio epididimal del perro. Int. J. Morphol., 23(4):337-344, 2005.

RESUMEN: La cisterna del aparato de Golgi de las células principales del epidídimo del perro, fueron tratados con el método de tetróxido de zinc iodide-osmium (ZIO). Estas cisternas fueron observadas en la región supranuclear del citoplasma de las células principales del epidídimo. Abundante cisternas del retículo endoplasmático, cuerpos multivesiculares, mitocondrias, lisosomas y elementos vesiculares de tamaño variable, fueron encontrados en esta región, todos asociados con los sacos del aparato de Golgi maduro. El uso del método de ZIO facilita la observación e identificación del aparato de Golgi, permitiendo efectuar una correlación entre estructura y función en el área de Golgi. Estas características estructurales suponen el rol secretorio de las células epididimarias principales en el perro.

PALABRAS CLAVE: Epidídimo; Células principales; Aparato de Golgi; Método ZIO.

\section{REFERENCES}

Arrighi, S.; Romanello, M.G. \& Domeneghini, C. Ultrastructure of epididymal epithelium in Equus caballus. Ann. Anat., 175:1-9, 1993.

Bedford, J. M. The status and the state of the human epididymis. Human Reprod. Update, 9:2187-99, 1994.

Clermont, Y. \& Flannery, J. Mitotic activity in the epithelium of the epididymis in young and old adult rats. Biol. Reprod., 3:283-92, 1970.

Cooper, T.G. Role of the epididymis in mediating changes in the male gamete during maturation. In: Mukhopadhay, K. \& Raizada, M.K. Renin angiotensin systems. New York, Plenum Press, 1995. pp.87-101.

Flickinger, C. J.; Howards, S. S. \& English, H.F. Ultrastructural differences in efferent ducts and several regions of the epididymis of the hamster. Am. J. Anat., 152:557-86, 1978.

Flickinger, C. J.; Wilson, K. M. \& Gray, H. D. The secretory pathway in the mouse epididymis as shown by electron microscope radioautography of principal cells exposed to monensin. Anat. Rec., 210:435-48, 1984.

Goyal, H. O. \& Williams, C. S. Regional differences in the morphology of the goat epididymis: A light microscope and ultrastructural study. Am. J. Anat., 190:349-69, 1991.

Greenberg, J. \& Forssmann, W. G. Studies of the guinea pig epididymis. I. Ultrastructure and quantitative morphology of the principal cells. Anat. Embryol., 168:173-94, 1983.

Hamilton, D.W. Structure and function of the epithelium lining the ductuli efferentes; ductus epididymidis and ductus deferens in the rat. In: Hamilton, D.W. \& Greep, R.O. Handbook of Physiology. Washington: American Physiological Society, 1975. V. 5. pp.259-301.

Hermo, L. Structural features and function of principal cells of the intermediate zone of the epididymis of adult rats. Anat. Rec., 242:515-30, 1995.

Hermo, L.; Green, H. \& Clermont, Y. Golgi apparatus of epithelial principal cells of the epididymal initial segment of the rat: structure, relationship with endoplasmic reticulum, and role in the formation of secretory vesicles. Anat. Rec., 229:159-76, 1991.

Hoffer, A. P.; Hamilton, D.W. \& Fawcett, D.W. The ultrastructure of the principal cells and intraepithelial leucocytes in the initial segment of the rat epididymis. Anat. Rec., 175:169-202, 1973.

López, M. L.; Grez, P.; Gribbel, I. \& Bustos Obregón, E. Cytochemical and ultrastructural characteristics of the stallion epididymis (Equus cabalus). J. Submicrosc. Cytol. Pathol., 21:103-20, 1989.

Neutra, M. \& Leblond, C. P. Radioautographic comparision of the uptake of galactose $\mathrm{H}^{3}$ and glucose $\mathrm{H}^{3}$ in the Golgi region of various cells secreting glycoproteins or mucopolysaccharides. J. Cell Biol., 30:137-50, 1966.

Nicander, L. \& Malmqvist, M. Ultrastructural observations suggestiong merocrine secretion in the initial segment of the mammalian epididymis. Cell Tissue Res., 184:48790, 1977.

Nicander, L. \& Plöen, L. Studies on the regional fine structure and function in the rabbit epididymis. Int. J. Androl., 2:463-81, 1979. 
Ramos, Jr., A. S. \& Dym, M. Fine structure of the monkey epididymis. Am. J. Anat., 149:501-32, 1977.

Reinecke, M. \& Walther, C. Aspects of turnover and biogenesis of synaptic vesicles at locust neuromuscular junctions as reveled by iodide-osmium tetroxide (ZIO) reacting with intravesicular groups. J. Cell Biol., 78:83955,1978 .

Robaire, B. \& Hermo, L. Efferent ducts, epididymis, and vas deferens: structure, functions and their regulation. In: Knobil, E. \& Neill, J.D. The physiology of reproduction. New York, Raven Press, 1988. V. 1. pp. 999-1080.

Roberts, K. P.; Ensrud, K.M. \& Hamilton, D.W. A comparative analysis of expression and processing of the rat epididymal fluid and sperm-bound forms of proteins D and E. Biol. Reprod., 67:525-33, 2002.

Schimming, B.C. \& Vicentini, C.A. Histochemical study in the epididymis of the dog (Canis familiaris, L.). Rev. Chil. Anat., 18:69-74, 2000.

Schimming, B. C. \& Vicentini, C. A. Ultrastructural features in the epididymis of the dog (Canis familiaris, L.). Anat. Histol. Embryol., 30:327-32, 2001.

Vicentini, C. A. \& Orsi, A. M. Características citoquímicas e ultra-estruturais do epitélio de revestimento na parte distal do epidídimo do hamster (Mesocricetus auratus). Rev. Brasil. Biol., 49:291-301, 1989.

Vicentini, C. A.; Orsi, A. M.; Gregório, E. A. \& Mello Dias, S. Ultra-estrutura do segmento terminal do epidídimo no gato (Felis domestica). Rev. bras. Ciên. morfol., 2:2431, 1985 .

Voglmayr, J. K.; Sawyer, Jr., R. F. \& Dacheaux, J.L. Glycoproteins: a variable factor in surface transformation of ram spermatozoa during epididymal transit. Biol. Reprod., 33:165-76, 1985.
Correspondence to:

Prof. Dr. Bruno Cesar Schimming

Department of Veterinary Medicine

Agrarian Sciences Faculty

University of Marília

Av. Hygino Muzzi Filho, 1100,

CEP: 17525-902,

Marília, São Paulo,

BRAZIL

E-mail:brunoidish@uol.com.6r

Received : 29-07-2005

Accepted : 08-09-2005 